Semmelweis Orvostudományi Egyetem

Honvéd-Katasztrófa-Rendvédelem-Orvostani Tanszékcsoport

\title{
Gondolatok a járványokról, háborúkról, pandémiáról és a honvédelemröl
}

\author{
Prof. Dr. Svéd László ny. orvos altábornagy, $\mathrm{PhD}$, \\ Dr. Faludi Gábor ny. ezredes, PhD
}

\section{Kulcsszavak: Covid-19 (SARS-CoV-2), Magyar Honvédség, Közegészségügy- járványügy, fertőző betegségek, biológiai hadviselés, járvány, pandémia, katonaorvoslás, védőoltások}

Az emberiség történelme a háborúk története. Az elmúlt 3 ezer évben csak 260 év volt olyan, amikor ne lett volna háború. Ami meglepő lehet, hogy az 1854-55-ig tartó krími háború az első, amikor nem a járványos betegségek, hanem az alkalmazott fegyverek és harceljárások döntötték el a háború kimenetelét. A járványok és a fertőző betegségek ezek után is jelen voltak, sokszor meghatározói voltak a későbbi háborúknak is. Amikor a közelmúltban, illetve a napjainkban lezajlott Covid-19 járvány következményei felszámolásában és védelmi feladataiban a hadsereg helyét és szerepét, nem utolsó sorban helytállását dicséri mindenki, akkor nem szabad elfelejteni, hogy a hadseregek ezen a területen komoly tapasztalatokkal rendelkeznek. Különösen igaz ez a Magyar Honvédségre, melynek szakemberei már az 184849-es forradalom és szabadságharc időszakában, a Honvédség megszületése pillanatától, meghatározó szerepet játszottak a magyar közegészségügy és járványügy kialakításában és igencsak elismerésre méltó eredményeiben. A XIX. században a Monarchia hadseregében a koszovói békefenntartó feladatok során az akkori egészségügyi szolgálat malária járványt számolt fel, majd vett részt járványmegelőző feladatokban az I. világháború kitöréséig. A sors véletlen játéka, hogy NATO-tagságunk után néhány nappal a Magyar Honvédség szövetségi kötelékben végrehajtott első feladata a koszovói menekültek albániai menekülttáborban történő közegészségügyi-járványügyi biztosítása volt. Talán nem véletlen, hogy az újkori müveletek és speciális feladatok első mobil közegészségügyi-járványügyi intézetét, vagy inkább laboratóriumát a Magyar Honvédség telepítette. 
Több mint egy éve élünk együtt azzal a rendkívüli és mindenkit megviselő helyzettel, amely a világ szinte minden (192) országát sújtja, a Covid-19 (SARS-CoV-2) nevü vírus által okozott világjárványnyal. Az emberek igen nagy részére - akik most ezt a helyzetet kénytelenek átélni és valahogy elviselni, kezelni - élete során ilyen jellegü, ennyire hosszú ideig tartó bizonytalan, életveszélyeztetettséggel járó helyzettel még nem találkozott. A mai idősebb korosztály tagjai bizonyára még emlékeznek a XX. század ötvenes éveinek tuberkulózis, szamárköhögés, torokgyík, kanyaró és gyermekbénulási járványaira. Ezek mindegyike súlyos lefolyású betegség volt, még a jelenleginél is magasabb halálozási kockázattal, azonban nem a társadalom egészét, hanem meghatározott korosztályt - elsősorban gyermekeket - és veszélyeztetettségi kört - pl.: rossz közegészségügyi körülmények között élőket érintett. Az ezt megelőző igazán súlyos influenza világjárványt a „spanyolnáthát" - 100 évvel korábbról - csak leírásokból ismerjük, de az ázsiai, hongkongi és az orosz pandémiára már sokan emlékezhetnek. A nagy tömegekre veszélyt rejtő fertőző betegségek - Ebola, SARS, MERS, Malária, Zika stb. - szerencsénkre nem szélesedtek pandémiává, hanem egy-egy körülírt területen, (endémia) pusztítottak sokszor világszerte nem kis riadalmat keltve.

Most teljesen mással szembesültünk, ami időnként már-már sorsszerünek van nyilvánítva, elsősorban a természeti és az ökológiai egyensúly megbontására hivatkozva, amiben véleményünk szerint is sok igazság rejlik.

A jelenlegi járvány minden társadalmi réteget és feladatot érint, így a felszámolásában résztvevő erők és eszközök is sokszínüek. A legnagyobb nyomás az egészségügyre nehezedik, melynek hely- zete az abszolút értelembe vett katasztrófa helyzetnél is rosszabb, hisz az ellátók és az ellátandók közötti mindennemü diszkrepancia a járvány kezdete óta nem került, de nem is kerülhetett feloldásra. Nyilván az ezzel kapcsolatos polemizálás nem ennek a tanulmánynak a feladata.

A Magyar Honvédség - minden elfogultság nélkül - jelentős szerepet vállalt a járvány és következményeinek felszámolásában. Jóleső érzés a sok elismerő megjegyzést hallani, véleményt olvasni a feladatban résztvevő katonák helytállásáról, magatartásáról és hozzáállásáról. A még mindig jelentősnek tekinthető társadalmi kapcsolataink révén igen sok örömteli dicsérő szó és gondolat jut el a végpontokon szolgálatot teljesítő katonákról. Sokan és jelentős fórumok teszik fel a kérdést: mi az oka annak, hogy a Honvédség felvállalja ezeket a feladatokat, miért teljesít így, és egyáltalán a haderőnek milyen kapcsolata, szerepe van a járványokkal, azok megelözésében, valamint a következmények felszámolásában. A magunk szerény eszközeivel, ismereteinkkel és tapasztalatainkkal, a megélt események tanulságaival megpróbálunk választ adni erre a kérdésre.

Ahhoz, hogy mindez közérthető legyen, vissza kell mennünk a múltba is, hisz Széchenyi mondása szerint a „múlton nyugszik a jelen, azon meg a jövendő."

Nem véletlen, hogy Szent János müvészi megfogalmazásában - az Apokalipszis lovasai, akik az emberi nem végromlásának okait szimbolizálják, mindig együtt lovagolnak, miként a tapasztalat szerint is korokon átívelően mindenkor összetartozó fogalmak voltak: az éhínség, a járvány, a háború és a halál (Jelenések könyve).

A feljegyzések tanúbizonysága szerint Xerxes 1,5 milliós perzsa serege 
Thessaliában 500000 embert vesztett föként vérhas miatt, és kénytelen volt lemondani Görögország meghódításáról. Spárta és Athén vitájában a pestis mondta ki a végső szót, áldozatul ejtve magát Periklészt is. Hippokratész, az ókor és az egyetemes orvoslás egyik legkiemelkedőbb alakja ekkor állapítja meg, hogy „a pestis a háborúk betegsége", de a többi hírhedt betegségről, mint a himlö, a tífusz és a vérhas is említést tesz.

A XIII. század keresztes háborúiban a szentföldi hadjáratok során VII. Lajos félmilliós serege pestis, tífusz és vérhas miatt teljesen felőrlődött, harcképességét elveszítette. A hazatérő keresztes hadak katonái hurcolták szét Európában a himlőt és a leprát. Az egyedi járványfolyamatok mögött a müködö járványtani törvények húzódnak meg: a hadjáratok jelentős fogékony embertömegeket kényszerítettek szük helyre, siralmas higiénés viszonyok közé. Az alultápláltságtól, fizikai megterheléstől, fáradtságtól kimerült, sebesült katonák, vagy az éhezéstől, fáradtságtól elgyengült menekülők áradatai biztos alapot képeztek a fertőző betegségek terjedéséhez. A rossz higiénés körülmények között élő leromlott népességet (katonát és civilt együtt!), a kirobbanó járványok könnyüszerrel tizedelték meg [1].

1330-ban, a haditechnikában megjelenik a lőpor és ettől kezdve a háborúkban a lőfegyverek alkalmazása kerül egyre inkább előtérbe. A haditechnikai/ hadászati fejlődés ellenére azonban a járványok továbbra is a legveszélyesebb követői maradtak a háborúknak és jóval nagyobb áldozatokat követeltek, egyes csaták sorsát is eldöntve, mint az alkalmazott fegyverfajta, vagy harcmodor [2].

Ennek bizonyítékaként, no meg feltehetőleg az első igazi tudatos biológiai fegyver alkalmazásának eredményeként
- igazolva ezzel azt, hogy a biológiai csapás kiváltása is egyidős a hadviseléssel -, meggyőző példaként szinte kötelezően említendő, Kaffa (a mai Feodosszija) városa bevételének története. 1347-ben az ostromló tatárok, a közöttük elsősorban a tevék miatt állandóan kisebb-nagyobb mértékben előforduló (endémiás) pestises betegek tetemeit is bedobálták hajítógépeikkel. Az így elszabaduló mesterségesen kialakított járvány megtörte a védők ellenállását. Az időbeli egyezések miatt nem lehetetlen, sőt egyre valószínübb, hogy az innen hajókon menekülö lakosok hurcolták szét és indították el a XIV. század lakott világának nagyobb részét Európát, valamint Kis-Ázsiát végig pusztító Fekete Halált, amely három év alatt elnéptelenítette az addig virágzó, lakott Grönlandot is. Jelenleg ezt a járványt tartják világelsőnek, nyilván a pusztítás és az áldozatok számának nagysága alapján is.

Ma már az is vitathatatlan, hogy az európai középkor sötétjében, a kezdetleges civilizációs színvonalon élő tömegek között a kor emberének számos fertőzőbetegséggel, járvánnyal kellett állandóan együtt élni, és átvészeléssel (nem áldozatok nélkül) megszerezni számos fertőzéssel szemben az ellenálló képességet. Amikor az első felfedezők a hajóikról partra léptek, természetesen magukonmagukkal vitték a számukra már ártalmatlan kórokozókat az immunológiailag védtelen amerikai őslakosság közé. Az indiánokat európai kórok pusztították. 1519-1521-ben az Azték-Birodalomnak Hernando Cortez (1485-1547) vezette spanyol hadak általi lerombolásával az őslakosok között kitört a himlőjárvány, amikor is Mexikó őslakosságának körülbelül kétharmada pusztult el a járványban. A himlö mellett tömegesen pusztított a tífusz, az influenza, a sárgaláz, a 
mumpsz, a kanyaró, és a kolera is. Ezek a betegségek a velük szemben védtelen latin-amerikai lakosság 90\%-át pusztították el. A behurcolás az indián népesség, előbb a latin-amerikai majd észak-amerikai indiánok - törvényszerü - tömeges pusztulását eredményezte [1].

Az első olyan háború amely ebben az állandóságban a járványok meghatározó, mindent eldöntő szerepében változást hozott, és ami egyben a katonaorvoslás jelentős, meghatározó kulcspontja a Krími háború (1854-55) volt. Az osztályozás, mint a tömeges sérültellátás alfája és omegája, ekkor válik igazolt, elfogadott katonaorvosi eljárássá. Az amputációk korszerüsítése, a tábori körülmények között narkózisban elvégzett mütétek lehetősége, nagyságrendje, a végtagsérülések gipszrögzítése, a tábori körülmények közötti ápolás és egyáltalán annak szervezett volta, mind ennek a háborúnak köszönhető.

A Krími háború francia és angol sebesült ellátási tapasztalatai igazolták, hogy nem csak a virtuóz sebészetre (franciák) de szervezett belorvosi - infektológusi ellátásra (angolok) és jól szervezett ápolásra is szüksége van a hadseregeknek, amit a két hadsereg kolera halálozási különbsége bizonyított. Ugyanebben a háborúban is meghatározó tényezővé váltak a fertőző betegségek, de nem akkora mértékben, mint az előzőek során. A tapasztalatok alapján vált tejessé a katonaorvosi szolgálatok felépítése (sebészet és belgyógyászat együtt). A porosz-francia háború 1870-1871 igazolta az elképzeléseket. Ez volt az első európai háború, ahol kisebb volt a fertőzőbetegségek okozta eü. veszteség, mint a harctevékenység okozta veszteségek, hála a mindkét oldalon alkalmazott integrált, akkor új típusú egészségügyi szolgálatok működésének [2].
A XIX. század második felének ipari forradalma jelentős befolyásoló tényezőként játszott szerepet, elsősorban a védőoltások (himlö, kolera) felfedezése és tömeges alkalmazása, valamint az egészségügy specializációjának további alakulása miatt.

A XX. század, sok háborút és rengeteg felfedezést eredményezett az orvostudomány - azon belül is a különböző fertőzőbetegségek megelőzésének és gyógyíthatóságának területén. Az I. világháború előtt már több védőoltás is rendelkezésre állt, de a hadseregekben nagy tömegeket érintő hastífusz és vérhas megbetegedések ellen hatékony megelőzési lehetőség nem volt. Kiemelt jelentőségü, gyakorlatilag alig ismert magyar vonatkozású felfedezést tett és a saját magán végzett kisérletekkel bizonyította 1916-ban, az akkori Honvédkórház bakteriológiai, később patológiai laboratóriumának vezetője dr. Feistmantel Károly törzsorvos - a hatékony hastífusz elleni védőoltást. Az azonnal bevezetett védőoltások hatására ettől az évtől kezdve, a megbetegedések száma a felére csökkent. A felfedezés helyszíne mind a mai napig megtalálható a kórház gazdasági bejárata melletti régi patológia épületében.

Az I. világháború azonban járványügyi szempontokból teljesen más ok miatt híresült el. 1918-ban kezdődött és még 1919-ben is dúlt, a Föld lakosságának 3-5\%-át elpusztító „spanyolnátha”. Az elnevezésnek semmi köze Spanyolországhoz csak annyi, hogy mivel ők nem vettek részt hadviselő félként a „Nagy Háborúban" a hírügynökségeik ráértek a hadijelentéseken kívül más, a világot érintő eseményekről is tudósítani. Így a világ a spanyolokon keresztül értesült a betegség megjelenéséről és pusztításairól. A betegséget az „influenza A” nevü vírus okozta. A járvány terjedésében 
és a földrészek közötti áthurcolásban az amerikai hadsereg, továbbá a háború meghatározó szerepet játszott. A betegséget az USA-beli Kansas-ból egy katonai bázison kialakult megbetegedési gócból az Európába onnan áttelepített katonák terjesztették és tették „világméretü" járvánnyá. A helyzetet nehezítette, hogy akkor védőoltás még nem létezett, az antibiotikumokat sem fedezték fel, így rengetegen nem is a vírus által okozott betegségben, hanem a különböző bakteriális felülfertőződés szövődményeibe haltak bele [3].

A „Nagy Háborút” megelőzően Magyarországon több, ma már gyógyítható fertőző betegség fordult elö, melyek kordában tartására és felügyeletének szigorítására a magyar királyi belügyminiszter 6405/1914.B. M. sz. körrendeletben július elsejei hatállyal, kölcsönös közlésre kötelezte valamennyi szomszédos törvényhatóságot, a bejelentésre kötelezett fertőző betegségek vonatkozásában. Ilyen volt a kolera, a himlö, a tuberkolózis, a diftéria, a vérhas, a bujakor és a tífuszos betegségek. A rendelet célja az volt, hogy a fertőzés terjedésének a megakadályozására még időben meghozhassák a szükséges intézkedéseket, valamint felszámolhassák a fertőző gócokat.

A tuberkulózis esetében már a háborút megelözően is rendkívül magas volt a halálozási arány. 1914-ben több mint 55 ezer, míg a rákövetkező évben már a 63 ezret meghaladta a betegségben meghaltak száma. 6555 fó hétéven eluli gyermek volt az elhunytak között.

A háborúk mindig együtt jártak a járványok terjedésével. A legtöbb áldozatot is ezek a betegségek követelték, nem pedig a hadmüveletek. A Nagy Háború idejére az orvostudomány és az egészségügy fejlődése mérsékelte ugyan ezeket az arányszámokat, de a harctereken ismét felütötték a fejüket a különböző járványos megbetegedések.

A kolera Ázsiából származott, és 1817-ben került az öreg kontinensre. Jellemző tünetei voltak az állandó hasmenés, hányás, levertség és szédülés. Súlyosabb esetekben a szervezet képtelen volt pótolni a folyadékveszteséget. Így a kórkép halálos kimenettel járt. A háború kezdetekor a rossz higiéniai viszonyok és a nyári hőség is hozzájárult a járvány kitöréséhez. Az osztrákmagyar hadseregben nagy gondot fordítottak a megelőzésére. Tilos volt mosatlan gyümölcsöt, zöldséget és nyers tejet, valamint fertőtlenítés nélküli vizet fogyasztani. A drasztikus módszerek között olyanok szerepeltek, mint a napi három csepp jódtinktúra vagy a napi 300 gramm higított sósav fogyasztása, amelyből öt napon keresztül, az étkezés elött tíz cseppet kellett egy fél pohár vízben feloldani és meginni.

Jelentések - a betegséget illetően kezdetben a katonai alakulatoktól, a vasútvonalak mentén fekvő településekről és a katonai kórházakból érkeztek. Már 1914 őszén jelentkezett a járványveszély. A kórt Oroszországból hurcolták be a sebesült és szabadságolt katonák, valamint az orosz hadifoglyok. A kormányzat intézkedései nem jártak eredménynyel, ugyanis a betegség lappangási ideje kettő és 21 nap között van, ezért a harctéri betegmegfigyelő állomásokon kötelezően eltöltött öt nap nem volt elegendő a betegek teljes bizonyossággal való kiszüréséhez. A hátország kórházaiba tünetmentesen került kórokozóhordozók a lappangási időszakban tovább fertőzték a környezetüket. A kórházakban, valamint az úgynevezett lábadozókban a sebesült katonák szükségszerüen polgári személyekkel is érintkeztek. Ezért a kór a lakosság körében is nagymértékben 
terjedt. A helyzet drámai volta mutatja, hogy az ország területéről 1915. július 26. és augusztus 1. közötti időszakban 600 új kolerás megbetegedésről számoltak be, amelyek közül 529 volt a polgári személyek száma, az elhunytaké pedig 292. A magyar királyi belügyminiszter 1915. október 24-én rendeletben intézkedett a polgári lakosok védőoltásáról. Törvényi alap híján azonban nem tehette kötelezővé, mindössze ajánlani tudta azt.

Ugyancsak az év augusztusában szintén rendeletben szabályozták a rongygyüjtést, illetve a kivitelt. Fertőzött településekről tilos volt rongyokat szállítani. A hazai textiliparnak azonban fontosak voltak ezek a termékek, ezért a rendelet kimondta, hogy megfelelö fertőtlenítés után folytatható a gyüjtés. A kolera ellen a hadseregben bevezették a kötelező védőoltást, amely 1916 januárjára eredménnyel járt.

A leggyakoribb betegségeknek a hastífusz és a vérhas számítottak. Legfőbb hordozói a harcterekről hazatérő sebesült katonák voltak, hiszen mozgásukkal terjesztették ezeket a megbetegedéseket. Sokszor nyitott vagonokban utaztak haza a harcterekről, a vasúti megállóknál és a tisztálkodóhelyeknél akaratukon kívül adták tovább a fertőzést.

$\mathrm{Az}$ északi frontól, valamint a Balkánról már 1914 decemberének végén viszont kiütéses tífuszos betegséget jelentettek. A hadvezetés azonnal intézkedéseket hozott a fertőzöttek kiszürése céljából. Azokat a katonákat, akiken a betegség jeleni mutatkoztak, a hadtápkörletben elkülönítették és nem szállították vissza őket a hátországba. Azonban itt sem tudták az összes fertőzöttet kiszürni akárcsak a kolera kapcsán, mivel a betegség leginkább a tünetmentesen fertőző sebesült személyekkel került a hátországba.
A rendkívül rossz higiéniás viszonyok miatt az emberek ruháját tetvek lepték el, amelyek a kiütéses tífuszt terjesztették. A belügyminiszter ezért 1914. december 26-án rendeletet adott ki a fertőtlenítésre. Úgynevezett fertőtlenítőállomásokat hoztak létre, megfelelő fertőtlenítőszerekkel. Ezeket a szabályokat nem csupán a sebesült és szabadságolt katonáknak, hanem a hadifoglyoknak, valamint menekülteknek is be kellett tartani. Egyes hadifogolytáborokban $90 \%$ is volt a Ty.ex fertőzöttség mértéke.

Szintén nagyon elterjedt volt a hastífusz, amelyet ugyancsak a nem megfelelő körülmények, illetve a tisztálkodás hiánya okozott. 1915 áprilisában rendelték el a védőoltást. A szegények és nincstelenek számára a vakcinát az Országos Betegellátási Alap biztosította. A legfontosabb volt ezeknek a fertőzött betegeknek az elkülönítése.

A spanyolnátha 1918 októberében ütötte fel a fejét, leggyakrabban torokfájással kezdődött, majd nagyfokú hányás és magas láz kísérte. Súlyos légzőszervi szövődmények léphettek fel, amelyek rendkívül hamar képesek voltak elvinni a beteget. A kórkép leggyakrabban a felnőtt lakosság 20-40 év közötti körében elterjedt el. Amíg az országban 1914-ben 471-en hunytak el a fertőzés következtében, addig 1918-ban már több mint 53 ezren. Az antibiotikumokat még nem ismerték, ezért a betegség általános súlyos tüdőgyulladás következtében pár nap alatt végzett áldozatával. A kór ellen meleg, cukrozott teát, a változatos táplálkozást, illetve a meghülés és a fárasztó munka elkerülését javasolták.

A himlő kapcsán az egészségügyi hatóságok úgy vélték, hogy hamarosan eltünik a betegségek sorából. A lakosság himlö elleni oltottsága megfelelőnek tünt és a mortalitási adatok is alacsonyak voltak. 
Évente átlagban 128 eset történt. Azonban a háború második évében, 1915ben felütötte a fejét a hólyagos himlö, és már ekkor 1800 halálos áldozatot követelt. 1916-ra ez a szám 6200-ra nőtt. Ez elsősorban Szlavóniában és ÉszakkeletMagyarországon okozott gondot. Későn kezdtek el védekezni ellene, ezért az egész országra átterjedt, 1917-re azonban a kényszeroltásoknak köszönhetően sikerült megfékezni.

A különféle fertőző betegségek elszaporodása arra késztette az egészségügyi főhatóságot, hogy rendeletben nyomatékosítsa és ismételten kötelezze az elöljárókat a betegségek bejelentésére, a kórleírására, valamint a páciensek ellátását szolgáló kórházi helységek felállítására és a fertőzöttek elkülönítésére. A betegek elszigetelése azonban lehetetlen volt, hiszen a kórházakban így is jelentős helyhiány volt tapasztalható. Sokszor még a hátországba érkező sebesülteket sem tudták ellátni. Sok nagyobb épületet ezért hadikórházzá alakítottak át. Ilyen volt Budapesten a Mücsarnok épülete is. A gyógyítás rendkívül nehézkes volt, hiszen jelentős orvos- és ápolóhiány lépett fel. Ugyanis sok másodorvos szintén a frontokon harcolt. A kórházi főorvosok egy része pedig helyi katonai szolgálatot teljesített. A másodorvosok helyére gyakran orvostanhallgatókat, illetve szigorló orvosokat állítottak be. A kórházi ápolószemélyzet jelentős részét tették ki az apácák, akiknek rendszeres elméleti és gyakorlati képzését nem szervezték meg. A világi ápolónők oktatásáról az 1883-ban alakult Magyar Vöröskereszt gondoskodott, de még így is sokan dolgoztak mindenféle képzettség nélkül [4].

A két világháború között az orvostudomány - még mind a mai napig érvényes - felfedezései, kutatásai, és a mai léptékkel mérve is óriási fejlődése, alapjaiban változtatták meg az egészségügy hatékonyságát, eredményességét, a megbetegedési viszonyokat, arányokat, a betegségek lefolyását, gyógyíthatóságát. A járványok és a fertőzőbetegségek szempontjából két lényeges dolog történt ekkor. Az egyik az antibiotikum felfedezése, a másik pedig a még le nem győzhető baktériumok fegyverként való használata lehetőségének a kipróbálása.

A világháborúra készülő kis- és középhatalmak mindegyike valamilyen formában figyelmet fordított a biológiai fegyverek fejlesztésére:

\section{A japán fejlesztési törekvések}

A II. világháború során kezdődött meg az első generációs biológiai fegyverek kifejlesztése, amelyek során eleinte a természetes járványfolyamatok pontos leutánzásával, a járványok irányitott keltésével, kívánták megoldani a katonai célok elérését. Ennek a tevékenységnek egyik fő kiművelője a császári japán Kvantung-hadsereg volt Mandzsúriában. Az Isii Siro orvos altábornagy vezetésével 1932-ben létrehozott speciális 731-es alakulat és a Vakamacu állatorvos vezérőrnagy vezette 100 -as különleges egység több száz kilogramm pestis, kolera, lépfene, tífusz tenyészetet állított elő. Fertőzött bolhák és rágcsálók tömegét tenyésztették járványok keltése céljára. A kórokozók tömegtermelése mellett a biológiai fegyver alkalmazásának számos más körülményét is kikísérletezték: az éhező lakosság számára tífusszal fertőzött zsemléket hagytak hátra, pestissel fertőzött bolhákat szórtak le repülőgépről Nimpo város körül 1940-ben, igen eredményesen komoly járványt váltva ki. 1942-ben az ún. „harmadik expedíció" során a stratégiai visszavonulást végrehajtó japán csapatok a kiürített te- 
rületeken a víznyerő helyeket előzetesen szennyezték, folyókat, tavakat, mesterségesen fertőzött foglyokat bocsátottak szabadon, fertőzött süteményeket „veszítettek el".

A biológiai hadműveletek során pestis, lépfene, hastífusz és paratífusz kórokozók nagy mennyiségét használták fel sikeresen, kidolgozva a fertőzött legyek élő célba juttatására szolgáló $25 \mathrm{~kg}$ súlyú Uji porcelánbombát, főleg polgári célpontok ellen, és a „Ha” nevü hasonló rendeltetésű acéltestű 1500 fertőzött repeszbombát katonai célpontok leküzdésére.

\section{A német elképzelések}

A biológiai fegyverek fejlesztésének német programja 1936-ban kezdődött, de az intenzív fejlesztést Adolf Hitler parancsa 1942-ig, a sztálingrádi vereségig szigorúan tiltotta, annak ellenére, hogy a francia és belga területek elfoglalásakor, az ott talált katonai intézetekből (pl. Le Bouchet-ból) a német hadvezetés sok ismeret birtokába került.

A japán módszerektől eltérően, teljesen új irányokba kezdték meg a fejlesztést. Létrehozták a biológiai fegyver egy új, valóban hatásos alkalmazási módszerét, ami ezt ténylegesen napjaink hatékony tömegpusztító fegyverévé tette - a bakteriális aeroszolt, és előállításának modern követelményeket is kielégítő eszközeit: az elektromágneses aeroszol-generátort és a nagy belső nyomású üvegbombát (Himmler gun), amely az explózió során állította elő az ún. robbanó aeroszolt.

Érdemes elgondolkozni azon, hogy a náci hadvezetésnek minden a kezében volt, ami akár ma is a legkorszerübb biológiai hadviseléshez szükséges (a ballisztikus rakétatechnika [V2] és az aeroszol felhő alkalmazásának ismerete).
Az offenzív biológiai hadviselésre az angolszász szövetséges hatalmak a negyvenes években kezdtek felkészülni. A titkosságát vesztett anyagokból megtudható, hogy 1940-ben egy kis egység kezdte meg müködését Porton Downban, hogy a biológiai fegyverek vonatkozásban és a szükséges ellenintézkedések kidolgozása céljából kutatásokat folytasson, az ún. „N-bomb project” keretében. A kutatások végső szükség esetére, a bosszúállás fegyverének a megalkotását célozták, amelynek kialakításához a lépfene aerob spórás kórokozóját választották - cluster légibombába töltve - felhasználásra. A fejlesztési munkálatok során kísérleti területfertőzés is történt a brit felségvizeken fekvő Gruinard-szigeten (Skócia partjainál), amelyre csak az 1986-ban végrehajtott teljes dekontaminálás után, 45 év elteltével, lehetett újra belépni a fertőzés tartósan fennálló veszélye miatt. $\mathrm{Az}$ angol-kanadai tervezethez később az USA is csatlakozott. Az angliai defenziv kutatások nem, még az offenzív kutatások csak 1957 végén álltak le.

\section{Az amerikai kutatások}

1941 végével kezdődtek meg Fort Detrickben, fóként a humánpathogén mikróbák és toxinok vonatkozásában, amely programot később egészítettek ki állat- és növénypatogén kórokozók kutatásával is. A biológiai hadviselésben rejlő lehetőségek vizsgálatára kiterjedten alkalmazták az imitáló eljárásokat, amihez az apatogén spórás Bacillus globigii (BG)-t mai nevén Bacillus subtilis var. niger-t és a Serratia marcescens- $\mathrm{t}$ használták, amelyet tömegméretekben állították elő és aeroszolfelhőben alkalmazták, megfelelően kontrollált feltételek mellett. A hidegháborús évek alatt 239 alkalommal kisebb és nagyobb városok, tengeri partszakaszok és nagy- 
városok metrórendszerében végeztek vizsgálatokat az alkalmazás optimális feltételeinek meghatározására $(10,13)$. Az anthrax kórokozója mellett számos újabb biológiai fegyver gyártására alkalmas kórokozó pl., tularemia, Q-láz és sárgaláz laboratóriumi kutatása is elkezdődött.

A sárgaláz esetében a kiválasztást az is segítette, hogy az északi féltekén a betegség kórokozója ismeretlen, ezen vírussal szemben a természetes átvészelés útján szerzett ellenálló képességre a lakosság körében nem kell számítani. A vírus célba juttatására, mint a természetben is, a fertőzött szúnyog, mint átvivő (vektor) szerepelt. A sárgaláz biológiai fegyverként való alkalmazásához szükséges tömeges szúnyogtermelés 1959-re Fort Detrick-ben elérte a napi fél millió élő szúnyogtermelési kapacitást. A repülőbombából vagy rakéta-robbanófejből kiszabaduló szúnyogok néhány kilométer sugarú körön belül csípésükkel, nagy biztonsággal terjeszthették volna el a kórokozókat.

A Manhattan tervhez hasonló titkossággal kezelt biológiai fegyverfejlesztési programokban tovább optimalizálták a bevetési lehetőségeket. Tanulmányozták a mikrobiális aeroszol felhőként alkalmazott biológiai fegyverek terjedését befolyásoló körülményeket, az 5 mikronos optimális cseppátmérőtől kezdve, a kijuttatáshoz szükséges meteorológiai feltételek szélső értékéig. Vizsgáltak minden körülményt, beleértve a kijuttatás számos lehetséges eszközét is, a légi eszközöktől a spray tankig. A kutatások tisztázták a természetben található kórokozókból előállított biológiai és toxin fegyverek elméleti és gyakorlati alkalmazási feltételeit. Az Egyesült Államok hadseregének offenzív biológiai fegyver kutatási programja R. Nixon elnök rendeletére, az USA egyoldalú kötelezettség vállalásaként, 1969-ben szüntette be müködését. A defenzív kutatások soha sem álltak le.

\section{A Szovjet biológiai fegyver története}

A szovjet biológiai fegyverkezés már az 1930-as évek elején megkezdődött. Az első titkos kutató laboratóriumokat Tabolszkban alapították meg 1931-ben. A GPU 1933-ban Szuzdalban hozta létre a Pokrovszkij Kolostorban, a saját kutató-fejlesztő bázisát. A Zacsatyevszkij Templom laboratóriumi állatokkal volt tele. A lakosság növekvő félelmei miatt az objektum 1935-ben a Kalinyin környéki Szeliger tó szigetére költözött. Még 1933ban a Vörös Hadsereg szintén létrehozta saját $\mathrm{K}+\mathrm{F}$ intézményét Perkuskovoban, közel Moszkvához. A katonai vezetés alatt álló, később Kirovba költözött intézet az ötvenes években lényegében minden ismert kórokozóval foglalkozott: anthrax, tularaemia, brucellózis, pestis, venezuelai lóencephalitis, tífusz, Q-láz és botulinotoxin. Két titkos speciális lőteret 1954-ben alakítottak ki az Aral tónál, a Komszomolszk és a Vozrozsdenyijeszigeteken. A hatvanas években épültek termelö üzemek Szverdlovszkban és Zagorszkban. A szovjet kutatók az összes alkalmazási módot (légi bombák, rakéta robbanófejek, spray tartályok) kipróbálták. 1972-ben a Szovjetunió aláírta, valamint ratifikálta a Biológiai és Toxinfegyver Egyezményt, sőt az egyik társletéteményese lett az USA továbbá Anglia mellett. Mindazonáltal a szovjet vezetés még húsz éven át folytatta az offenzív biológiai programját. Az 1970-es években a hírszerzési adatok arra utaltak, hogy Aksu, Berdszk, Omutninszk, Pokrov, Szverdlovszk, Zágorszk (Szergijev Poszad) és Aralszk városok a biológiai fegyvergyártás, illetve fejlesztés központjai, nagy hütőbunkerekkel. Az is- 
meretekkel egybevágott az 1979-ben Szverdlovszkban (ma ismét: Jekatyerinburg) kirobbant baleset, amely során az elszabadult 1g anthrax spórákból kialakult felhő a város felett a széljárás szerint elnyúlva 66 életet követelt. A szovjet-orosz vezetés 1990 -ig letagadta még a balesetet is, azt kommunikálta, hogy a kórképek tüdőanthraxnak feleltek volna meg.

Csak 1992-ben sikerült bebizonyítani, hogy Moszkva Össz-szövetségi Tudományos Termelő Szövetség „Biopreparat" néven 6500 tudományos dolgozóval, offenzív biológiai fegyverprogramot valósít meg. A leleplezésre Vlagyimir Pasecsnyik angliai emigrációjával, majd K. Alibek amerikai emigrációjával nyílt lehetőség. Vlagyimir Pasecsnyik a Leningrádi Ultratiszta Biológiai Preparátumok Intézetének igazgatója volt. Kannatjan Alibek alezredes a hadsereg össz-szövetségi szintü tudományos igazgatója volt. A Biopreparat katonai alapítású, de később a Földmüvelési és Egészségügyi Minisztérium alárendeltségébe tartozó szervezetként müködött, mint kereskedelmi oltóanyag és reagens előállító szervezet. Évi költségvetése 100 millió régi rubel, 150 vezetővel, $1000 \mathrm{PhD}$-vel rendelkező szakemberrel és több mint 25000 dolgozóval. Első igazgatója V. Ogarkov marsall volt, ezért "Ogarkov rendszer" lett a Biopreparat gúnyneve, öt $J$. Kalinyin követte, aki korábban magas rangú tábornokként a Szovjet Hadsereg Vegyi csapatainak volt a fönöke. A komplex föleg Leningrád körüli városokban helyezkedett el St. Petersburg, Obolenszk, Koltszovo, Csehov). 1985-ig a feladat a tularémia és más baktériumok alkalmazásának kutatásából állt, 1984-től egy genetikailag módosított fokozott virulenciájú pestis törzs került a figyelem kö- zéppontjába. A „szuperpestis” ellenáll a hidegnek, és az antibiotikum rezisztenciája sokoldalú volt. Obolenszkben 2700 dolgozó, Koltszovoban Novoszibirszk közelében 6000 fö foglalkozott főleg a súlyos kimenetelű vérzéses lázak vírusaival. Csehovban a nyugati antibiotikumokkal szembeni ellenálló képesség kialakításán dolgoztak. Az Aral-tó két szigetén biológiai szabadtéri próbalőtér működött. A kísérletek következtében 1976-ban igen jelentős halpusztulás történt, majd 1988-ban fél millió antilop pusztult ki a Turgay sztyeppén, 1989-ben a pestis miatt pedig egész birkanyájak pusztultak ki a sztyeppén. A Biopreparat termelése 1987-ben elérte a $200 \mathrm{~kg} / \mathrm{hét}$ liofilezett pestisbaktérium előállítási kapacitást. A berendezések egy része, mint a kazahsztáni Sztyepnogorszk, kettősrendeltetésű termelöüzem volt, amely a később kialakított Mikrobiológiai és Orvosi Ipari Minisztérium hatáskörébe tartozott. A leleplezések hatására háromhatalmi tárgyalások kezdődtek az USA, Nagy-Britannia és a szovjet-orosz vezetés között 1990-ben, 1991-ben megnyitották a Biopreparat kapuit a nyugati szemlélők elött, és 1992-ben Jelcin elnök a No. 390-es elnöki rendelettel betiltotta a biológiai fegyvertermelés folytatását. Azt is Jelcin elnök ismerte el nyilvánosan 1992 májusában, hogy a szverdlovszki anthrax járvány valóban egy biológiai fegyvert termelö üzemében megtörtént baleset következménye volt [1].

Szerencsére ezek a fegyverek a japánok kivételével, nem kerültek alkalmazásra.

$\mathrm{Az}$ antibiotikum, mint preventív eszköz, az egészségügyi haderővédelem akkor még kezdetleges csírájaként az ÉszakAfrikai műveletekben került kipróbálásra és a szövetséges csapatoknál, a győzelemhez hozzájárulva. Kiemelt fontosságú az 
a tény is, hogy a szövetségesek számára rendelkezésre állt a főként a legyek, szúnyogok és tetvesség leküzdésére hatékony rovarirtószer, a DDT. Míg Rommel csapatait a különböző, az ottani éghajlattal öszszefüggö, fóként enterális (hasmenéses) betegségek (a személyi állományt több mint 50\%-ban) sújtották El Alamein-nél, addig a szövetségesek az antibiotikumoknak köszönhetően megmenekültek ezektől a harckészültséget és hadi alkalmazást gyakran nehezítö betegségektől.

A Keleti-fronton a csapatok mindegyikét, az áldatlan közegészségügyi viszonyok miatt a „kiütéses tífusz” és a vérhas járványok tizedelték.

Nagyon nehéz mérleget vonni az áldozatok száma, megoszlása és a különböző fertőző, valamint járványos betegségek összefüggéséről a II. világháborúban. Ez volt az első olyan háború, ahol a civil áldozatok száma jóval meghaladta a harci cselekményekkel összefüggő haláleseteket. A 75 millió halottból 20 millió volta katona és 40 millió körüli a civil áldozat. Ezen felül a náci faji és megszállási erőszakok következményeként 11-17 millió, a holokauszt áldozataként pedig 5-6 millió ember növeli az áldozatok számát.

A II. világháború utáni időszak helyi háborúiban már egy új veszélyforrás a vírusok okozzák az egészségügyi veszteség több mint felét. Az USA haderejének Vietnamban az összes egészségügyi veszteség 50-60\%-át a járványos fertőzőbetegségek okozták, amelyek mindegyikét valamilyen vírustörzs okozta. Kiemelkedik közülük - és ez mind a mai napig így van - a vírusos hepatitis (májgyulladás). Afganisztánban a szovjet 40 . hadsereg egészségügyi veszteségének $56,8 \%$-át okozta ez a betegség.

A délszláv válságban a szerb katonák 80\%-a szenvedett ebben a betegségben.
Megjegyzendő, hogy a Rákóczi szabadságharc észak-magyarországi hadjárata során 1703-ban, egy különös, sárgasággal járó megbetegedésekről írnak a magyar katonák körében.

Jelenleg ennek a betegségnek a nagyságrendje, előfordulási gyakorisága minősíti, mint indikátor, egy adott műveleti terület közegészségügyi-járványügyi helyzetét [5].

A történelmi előzmények abban segítenek, hogy a magyar közegészségügyi intézményrendszert és a Magyar Honvédség pandémiában betöltött helyét és szerepét megfelelö helyen tudjuk kezelni, értelmezni.

A fentiekből szinte logikusan következik, de bizonyítottan történelmi tény, hogy a Magyar Honvédségnek kiemelkedő és meghatározó szerepe van a közegészségügyi intézményrendszerünk kialakításában.

Dr. Markusovszky Lajos törzsorvos az 1848-49-es szabadságharc egyik jelentős katonaorvosa a magyar kormány megbízásából szerepet vállal a magyar katonaegészségügyi szolgálat létrehozásában. A második komáromi csata után ő kezeli Görgey Artúr fejsérülését, és vele együtt vonul el számüzetésbe, Klagenfurtba, ahonnan 1850-ben tér vissza. 1857-ben ő alapítja meg a mind a mai napig müködő Orvosi Hetilapot. Személye a későbbiek során meghatározóvá válik a magyar közegészségügy alapjainak lerakásában.

1866-67 között egy jelentős kolerajárvány alakult ki Pesten. Ennek a szomorú eseménynek, és a Kiegyezés után kialakult lehetöségeknek köszönhetően 1875-ben megszerkesztik, majd 1876ban elfogadják az „1876. évi XIV. törvényt a Közegészségügyröl”. A „Közegészségügyi Igazgatás" központi szerve a Belügyminisztériumba kerül. Ezt megelőzően, 
1868-ban Markusovszky Lajos aktív közremüködésével alakítják meg az Országos Közegészségügyi Tanácsot, melyet a jelenleg 1945. január 31-től működő Egészségügyi Tudományos Tanács jogelődjének tekintenek. 1885-ben pedig közegészségügyünk első apostolának is elnevezett Fodor Józseffel együtt megalakítja az Országos Közegészségügyi Egyesületet [6].

A magyar közegészségügy hírét és elismertségét jelentősen emelő személyek közül ki kell még emelni Högyes Endrét, aki az 1890-ben, az akkor megalakított budapesti Pasteur Intézet igazgatója volt.

A védőoltások megjelenéséig a járványok ellen egyetlen hatásos védekezési forma létezett, a lezárás a fertőző gócok és emberek elkülönítése, majd a betegségek természetének - elsősorban lappangási idejének - megismerése után a különböző ideig tartó teljes lezárás, a karantén. A XIX. század második felétől egyre-másra fedezték fel a különböző, addig pusztító és rettegett betegségek elleni védőoltásokat. A XX. század első felének a nagy felfedezése a penicillin, a bakteriális fertőzések legyőzésében felbecsülhetetlen segítséget jelentett. Az akkori Magyarország köszönhetően a jól szervezett és felkészült közegészségügyi intézményrendszerének az elsők között vezette be és tette gyakran kötelezővé a megjelenő védőoltásokat.

A történelmi hűség kedvéért sorrendben - most rövidnek tünő idő alatt - a következő védőoltásokat vezették be, illetve alkalmazták Magyarországon:

- 1884 Kolera

- 1887 Himlö

- 1938 Diphtéria (torokgyík)

- 1954 Di-Per-Te (torokgyík-szamárköhögés-tetanusz)

- 1954 BCG (tuberkulózis, TBC)

- 1957-1960 Polio (gyermekbénulás)
- 1969 Morbilli (kanyaró)

- 1989 Rubeola (rózsahimlő)

- 1990 Morbilli-Rubeola

- 1991 Az előző oltás a mumpsszal (fültőmirigy gyulladás) kiegészítve

- 1999 Hepatitis B (fertőző májgyulladás)

- 2000 BCG.

A 2000-től még számos és hatékony, illetve megújított vakcina jelenik meg úgymint a Varicella (bárányhimlő), Pneumococcus (tüdőgyulladás) HPV (humán papillóma vírus), Meningococcus (fertöző agyhártyagyulladás). A hatályos és világviszonylatban is szigorú magyar oltási szabályok szerint az előzőekben felsorolt védőoltásokból 6, illetve 12 éves korig 11 kötelezö. Ezen kívül 3 - HPV, Pneumococcus, Meningococcus - az ajánlott oltások között szerepel.

A Magyar Honvédségben jelenleg 7 védőoltás kötelező melyből hatot kombinációban Di-TE-mTY és a MorbilliMumps-Rubeola egyet pedig a Menningococus ellenit külön kapják meg. Természetesen a különféle és különleges nemzetközi feladatok, illetve missziók során az adott helyszínre specifikus oltások is kötelezőek. A NATO oltási ajánlásában 22 különböző vakcina szerepel, amelyből legtöbbet (19-et) az USA hadserege, majd ezt követően három ország - köztük Magyarország - 15 oltás használatát fogadta el [7].

A Magyar Honvédség közegészségügyi-járványügyi felkészültsége és a születésétől kezdve jelentős szerepvállalása, nemzetközi elismertséget szerzett, hadseregünk minden történelmi korszakában.

1897-ben a görög-török konfliktusban, békefenntartó erőként résztvevő 87. Osztrák-Magyar Monarchia lövészezredének speciális egészségügyi egysége 1897 júniusában egy malária járvány 
felszámolásában vett részt, majd 1907ben Koszovóban az Osztrák-Magyar békefenntartók az ottani menekülttáborok egészségügyi és közegészségügyi feladatait is ellátták. Az I. és a II. világháború, valamint a közöttük lévő időszak történeteiről már a visszatekintőben beszámoltunk. A Néphadseregi időszakra föleg annak első periódusában az igazi tömeghadseregre jellemzőek voltak a mostoha közegészségügyi viszonyok. A gyakori és a kora tavasztól késő őszig a gyakorlótereken eltöltött időszak közegészségügyijárványügyi biztosítása rendkívüli nehéz feladat volt. A fertőző és újonnan megjelenő betegségek, a tábori körülmények közötti személyi higiénia betartása sokszor megoldhatatlan feladat elé állította a szolgálatot. Elrettentéskép álljon itt egy a tatai alakulatnál bekövetkezett, rossz élelmiszerkezelési technológia miatt kialakult ételmérgezés, melynek során az alakulat vezetőorvosát - aki egyébként szabadsáságát töltve nem is tartózkodott az esemény során a laktanyában - kötél általi halálra ítélték 1953-ban [5].

Mindenesetre ennek az időszaknak a nehézségei iskolateremtő szerepet töltöttek be, és a szakterület növekvő szín- vonalon, elismertséggel tevékenykedett. 1974-ben megteremtődött a közegészségügyi-járványügyi felügyeleti rendszer. Nagy elismerést jelentett, hogy egyre több országos intézet vezetője vagy kiemelt munkatársa katonaorvos lett [5]. Elsőként kerültek kifejlesztésre különböző közegészségügyi-járványügyi laboratóriumok könnyen mobilizálható konténerekben. A nyolcvanas évek elején a tábori hadseregek után elvonuló három egészségügyi dandárban 12 tábori fertőző kórház és a szárazföldi hadsereggel együtt 10 darab Egészségügyi Járványügyi Osztag volt szervezve [8].

Ezek a fejlesztések a rendszerváltás időszakában és utána is folytatódtak, illetve a kutatók és fejlesztők a meglévő lehetőségekbe új eszközöket, köztük az országban egyedülállóan PCR elvégzésére alkalmas készüléket szereztek be. Ez a molekuláris mikrobiológiai kutatásokat tette lehetővé melynek eredményei, folyamatosan sikereket és elismeréseket szereztek a Magyar Honvédségnek. Ennek ellenére ebben a most rövidnek tünő időtartam alatt azért volt néhány kisebbnagyobb járvány a Magyar Néphadseregben, illetve a Magyar Honvédségben. Eze-

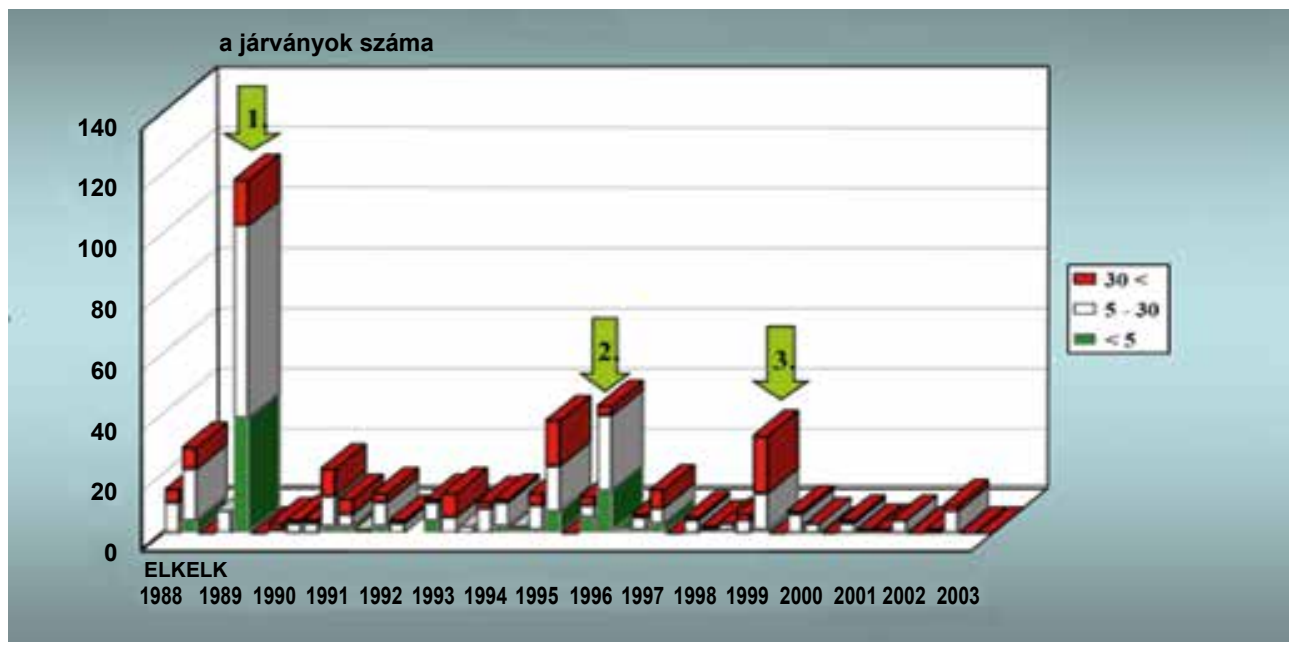

1. ábra. A Magyar Honvédség járványai 1988-2003 között [7] 


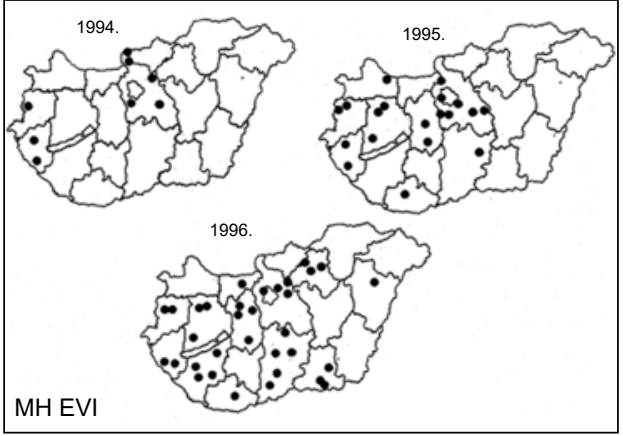

2. ábra. A Magyar Honvédség alakulatainál elöfordult rubeola járványok területi megoszlása 1994-1996 [7]

ket Dr. Faludi Gábor orvos ezredes egy Katona-Katasztrófaorvostani Társasági tudományos ülésén 2004-ben foglalta össze, melynek ábrái felidézhetik az akkori megbetegedések időtartamát és nagyságát.

Ebben az időszakban három kiemelt járványesemény következett be: 188889-ben országos kanyarójárvány részeként egy katonai kanyarójárvány, egy két éven át (1994-96) húzódó rubeola járvány, és egy meningitis epidemica (2000) járvány.
A kanyaró járványt az összehangolt civil és katonai járványügyi szoros együttműködéssel a polgári lakosság és 150000 katona újraoltásával sikerült megfékezni. A vissza-visszatérő rubeola járványt két év után szintén revakcinációval sikerült végleg legyürni, és ugyanez történt a szerencsére nem tömegesnek bizonyult invazív meningococcus esethalmozódás is, a mai COVID-19 járvány sokkal súlyosabb is lehetett volna, de az intézkedések és védőoltások eredményesek lettek.

1999-ben alig a NATO-tagságunkat ünneplő esemény után a koszovói menekültválság kezelésére indított NATO első és addig egyetlen tisztán humanitárius (AFOR NATO) albániai erők „Szövetséges menedék"-müveletben egy ilyen speciális feladatra alkalmas egészségügyi alakulatot kerestek. Ekkor - 1999. április 1-jei készenléttel - került megalakításra és a Magyar Honvédség első NATOfeladatát végrehajtó „KözegészségügyiJárványügyi Felderítő és Elemző Csoport". A NATO szintjén is első ilyen tábori körülmények között mobilisan

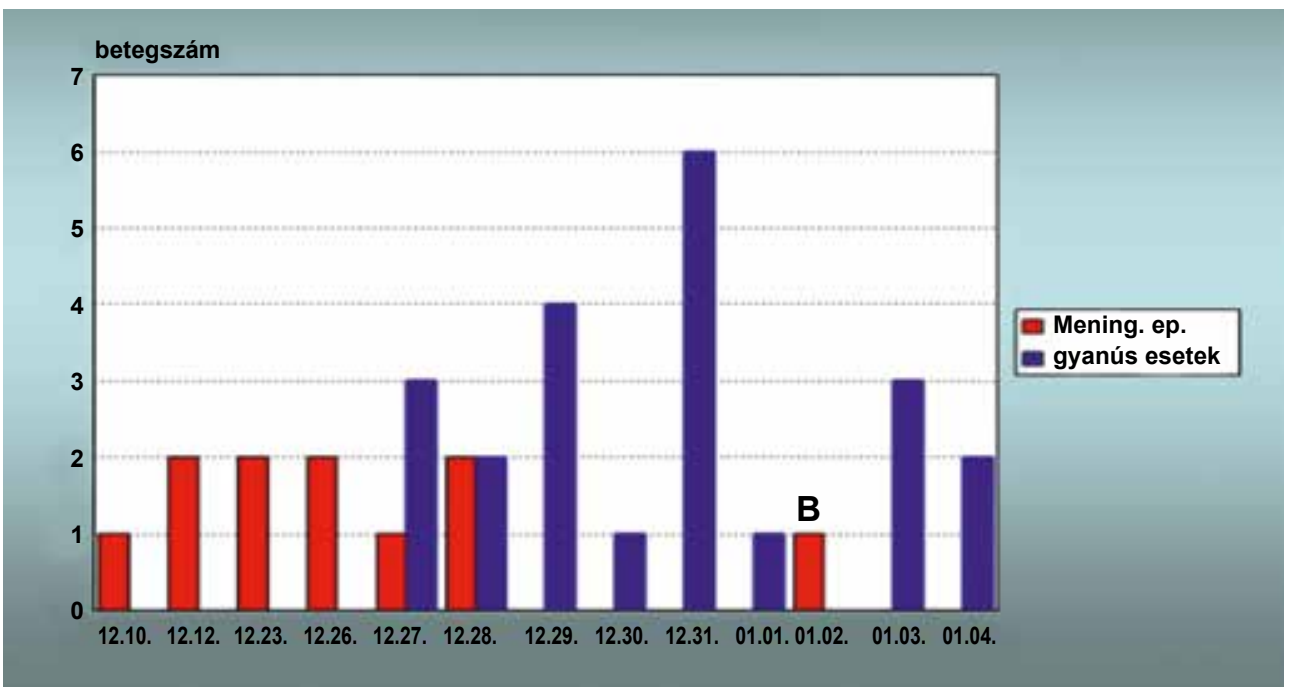

3. ábra. Meningitis epidemica megbetegedések és a betegség gyanújával kórházba felvettek száma, a Magyar Honvédségnél 1999. 12. 10. - 2000. 01. 04. [7] 
működő szervezet kiváló eredményeket ért el. A spanyol egészségügyi ellátókkal együtt a nyári nagy melegben az albániai Hamalajban, közel 40 ezer menekültet befogadó táborban semmilyen járvány vagy veszélyeztető betegség nem alakult ki. A munka elismerését bizonyítandó, hogy a csapat egy része és a teljes eszközpark áttelepült Albániából, a koszovói Pristinába, és „Pannónia” megnevezéssel biztosította - 10 évig magyar felügyelettel és állománnyal - a Balkán „Béke fenn- és megtartó" feladataiban résztvevő csapatok és nemzetek közegészségügyi-járványügyi biztosítását [9].

A mai napig is talán a legsikeresebb fejlesztés és járványügyben a legtöbb elismerést szerző „találmányunk”, innen Koszovóból ered. A KFOR-ban szolgálatot teljesítő katonák első csoportjának hazatérését követő - az akkor szintén elsőként elrendelt - úgynevezett visszaszürések során, a Magyarországon akkor már felszámoltnak tekintett tuberkulózisos betegeket - 7 föt találtunk. A kórokozó kimutatása nagyon hosszú folyamat volt akkor, közel két hetet vett igénybe a hagyományos módszerekkel. Ezt gyorsította fel az akkor már jól kipróbált - ma már mindenki által ismert és sajnos alkalmazott PCR, amellyel pillanatok alatt ki lehetett mutatni a kórokozókat.

2001. szeptember 11. ezt a módszert felértékelte. Az ismert eseményeket követően 2002-ben került megrendezésre a NATO prágai értekezlete, ahol a nemzetek a terror elleni küzdelemre ajánlhattak fel képességeket. Ekkor mi már tudtuk, hogyha a TBC-ét ilyen gyorsan ki tudjuk mutatni, akkor akár a lépfene (Anthrax) nem jelenthet akadályt. Magyarország ezen a NATO csúcson ajánlotta meg ezt a képességét, amit sokan nem akartak elhinni, de az elkövetkezendő időszakban főleg az amerikai

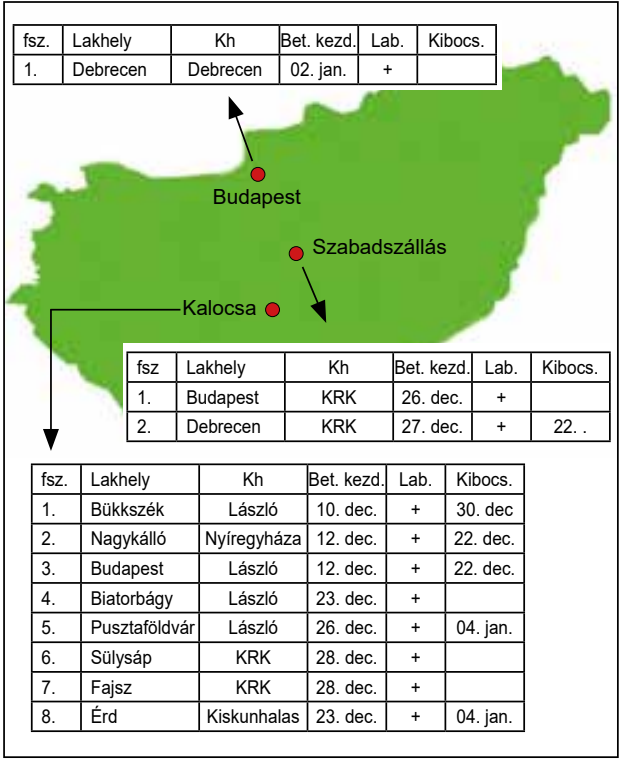

4. ábra. Megbetegedések

a Magyar Honvédségben

2000. január 06. 06.00-ig [7]

és német hasonló laboratóriumokkal szemben mindig gyorsabbak voltunk, ami ennél a betegségnél döntő, hisz az időben elkezdett antibiotikum kúra semmissé teszi a baktérium próbálkozásait. A „Molekuláris Mikrobiológiai Laboratórium" világhírnévre tett szert. A felszerelés dobozolt formából konténeres elhelyezésűvé vált. Ez a laboratórium biztosította az athéni olimpiai játékok biológiai fegyverek elleni védelmét, és számos NATO csúcs, hasonló jellegü ellátási feladatát.

A jelenleg a járvány harmadik hulláma leszálló ágának feladataiban való sikeres részvételnek ezek a meghatározó alapjai. A diagnózis felállításához országos szinten és azt segítve jelentős számú és biztonságos eredményü PCR tesztet végzett el az MH Egészségügyi Központ. Mobilis képességeit telepítette és a Molekuláris Mikrobiológiai Laboratórium folyamatos készenléti szolgálatot adott. Az MH Egészségügyi Központba telepített, 
és berendezett oltópontok száma, szervezettsége kiváló, hatékony. Az eddig beadott oltások száma körülbelül 180 ezer. Az oltóbuszok beszerzése, berendezése és müködtetésének szakmai megalapozása, zseniális, és az eddig leírtak hiteles összefoglalója.

Ne feledkezzünk meg arról, hogy a honvédség teljes személyi állománya érdekében végzett munka értéke a járványügyi mutatókban rejlik. Amikor ezeket nézzük, ne feledjük el: sok katonánk külföldi, és eltérő járványügyi feltételek között teljesít szolgálatot, így az ő védelmüket sem lehet sematikusan megszervezni, csak a medicina legfrissebb eredményeinek alkalmazásával.

Lehet, hogy kicsit idejét múlt, de mindenféleképp hiteles adatok 2020. december 12-i helyzetről szólnak, amikor is az MH Egészségügyi Szolgálat Főnöke $d r$. Kopcsó István o. ddtbk. (május 21-től vezérörnagy) az alábbiakban foglalta össze az addig ismert mutatókat: „Idehaza 744, misszióban pedig 6 katona volt koronavírus fertőzött. Egy fö honvédelmi alkalmazott és egy fö tartalékos katona hunyt el. Külszolgálatban egy fó állt kórházi kezelés alatt. Műveleti területről 14 föt szállítottak haza. A fertőzöttek mellett 2648 fő gyógyult meg. 1 fő katona van lélegeztető gépen. Az MH EK laboratóriumai eddig több mint 37 ezer vizsgálatot végeztek el a HM, illetve az MH részére." Ezen a napon, Magyarországon 276247 eset és 6784 fö halott volt [10].

$A$ védekezést jelentősen segítette és a járvány harmadik hullámának a Magyar Honvédség tekintetében kedvező eredményeihez nagyban hozzájárult az állomány aránylag korai időpontban végrehajtott védőoltása. A Magyar Honvédség egyik legnagyobb létszámú alakulatának a Magyar Honvédség Egészségügyi Központjának átoltottsága már március ele- jén megközelítette a 90\%-ot. A jelenlegi információk szerint az átoltottak aránya a Magyar Honvédség teljes állományát illetően $70 \%$ az első oltásban részesültek aránya pedig $80 \%$. Az MH EK Honvédkórházában a járvány teljes időtartama alatt 3523 fö koronavírusos beteget ápoltak. 2021. június 24-én egy fö igazolt beteg állt kórházi kezelés alatt [11].

Végezetül a jelenlegi oltási hajlandóság, bizonytalanság vagy inkább tudatlanság érdekében, egy záró idézetben fejezzük be az írásunkat, ami reméljük, segít a kételyek eloszlatásában. Az idézet nem napjainkban született, de segít a bizonytalanság eloszlatásában.

„Bármilyen immunizálás alkalmazásakor alapfeltételként kell szerepelnie, hogy az oltással járó kockázatnak mesze alatta kell maradnia annak a kockázatnak, amit a megbetegedés jelent."

Dr. Erdős Károly [7]

\section{Irodalom}

[1] Faludi G.: A Biológiai fegyver és az ellene való védelem-biovédelem (orvosi) kérdései. PhD Értekezés, 2012 ZMNE

[2] Svéd L.: Aktualitások és tények a katonaorvoslás történetéből. Honvédorvos, 2008, 59(3-4): 143-151.

[3] hu.wikipedia.org/wiki/spanyolnátha

[4] Molnár Z.: A járványos megbetegedések elleni harc Magyarországon a Nagy Háború időszakában. 1914-1918 Hadtudományi Szemle, 14(1): 125-138.

[5] Svéd L.: A Magyar Honvédség egészségügyi biztosítása elvének és gyakorlatának változásai, sajátosságai, különös tekintettel a haderő átalakításra, a NATO-ba történő integrálásra a különbözö fegyveres konfliktusok, valamint a békefenntartó béketeremtő és támogató tevékenységre. PhD Értekezés, 2003, ZMNE

[6] hu.wikipedia.org/wiki/Markusovszky_Lajos.

[7] Faludi G.: A Magyar Honvédség védőoltási politikája. MKKOT Tudományos Ülésen elhangzott előadás ábrái, 2004. 
[8] Svéd L.: A Magyar Néphadsereg Egészségügyi Szolgálatának története (1. rész). Honvédorvos, 2016, 67(/3-4): 31-90.

[9] Svéd L., Kopcsó I.: A Magyar Katona-egészségügy a jelenkor válságaiban. Katonai Logisztika, 2004, 12 (4): 61-92.

[10] www.honvedelem.hu

[11] www.honvedelem.hu

\section{Lt.Gen. (ret.) Prof. L. Svéd MD, PhD, Col. (ret.) G. Faludi MD, PhD}

\section{Thoughts on epidemics, wars, pandemics and on national defence}

The history of mankind is the history of wars. In the last 3,000 years, there have been only 260 years when there has been no war. What might be surprising though, is that the Crimean War of 1854-55 was the first one in which not the various infectious diseases, but the weapons used and combat procedures implemented decided the outcome of wars. Epidemics and infectious diseases remained present after this war as well and they often determined their outcome. When everyone praises the role and contribution by the armed forces in regard of managing the consequences of the COVID-19 epidemic, one must not forget that the armed forces have considerable experience in this field. This is especially true in regard of the Hungarian Defence Forces, whose experts played a decisive role in the establishment and very commendable results of the public health and epidemic system in the period of the War of Independence and Revolution of 1848-49, from the moment the Hungarian Defence Forces was born.

In the 19th century, during peacekeeping operations in Kosovo, the Medical Services of the Army of the Austro-Hungarian Monarchy eradicated a malaria epidemic and took part in epidemic prevention tasks afterwards, up until the outbreak of World War I.

It is a coincidence that a few days after Hungary became a full member in NATO, the first allied task of the Hungarian Defence Forces was to provide public health and epidemiological support to Kosovo refugees in an Albanian refugee camp. It is perhaps no coincidence though that the first mobile institute, or better say laboratory, of public health and epidemiological support to modern operations and special tasks, was deployed by the Hungarian Defence Forces.

Key-words: Coronavirus Disease (COVI-19), SARS-CoV-2, Hungarian Defence Forces, Public health and epidemiological support, Infectious diseases, Biological warfare, Epidemics, Pandemics, Military medicine, Vaccinations

Prof. Dr. Svéd László ny. o. altbgy., PhD 1134 Budapest, Róbert Károly krt. 44. 